\title{
THE STRUCTURE AND DEVELOPMENT OF THE
}

\section{GREENLAND-SCOTLAND RIDGE}

by

\author{
Tor H. Nilsen and Svend Saxov
}

\begin{abstract}
The Greenland-Scotland Ridge (GSR) is important to an understanding of the geologic history of the North Atlantic region. In particular, the plate-tectonic setting of such features as oceanic hot spots is well displayed along the ridge. Other features that can be better understood through study of the ridge include oceanic circulation patterns, the subsidence of aseismic ridges, the geochemical differences between hot spot produced oceanic basalts and mid-ocean-ridge basalts, the development of land bridges connecting drifting continents in diverging ocean basins, and the effects of such ridges on the evolution and migration patterns of marine megafauna and microfauna and of terrestrial vertebrate fauna and flora.
\end{abstract}

\section{Geological Development}

The GSR extends from the eastern continental margin of Greenland to the NW continental margin of Scotland and separates the North Atlantic Ocean from the NorwegianGreenland Sea (Figs. 1,2,3). The ridge is a composite feature that can be subdivided into six segments from NW to SE:

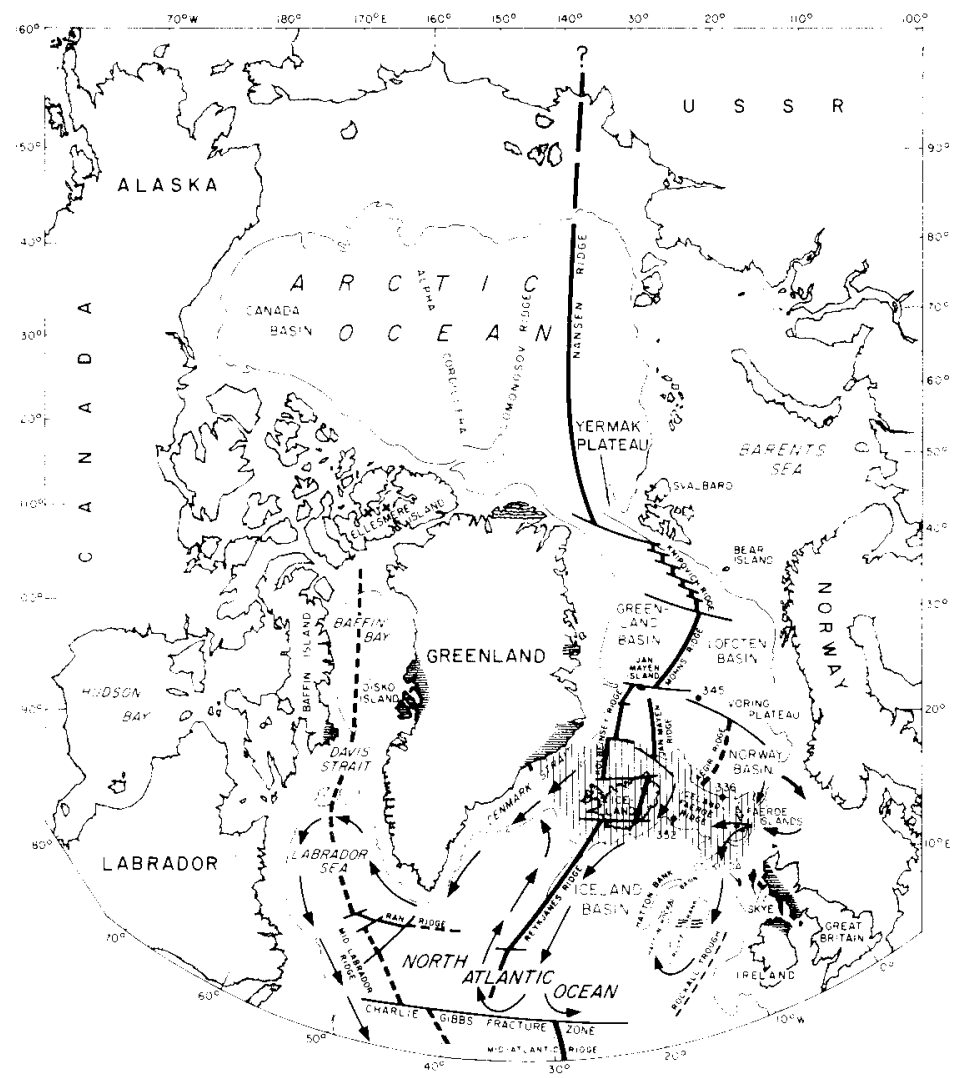

Figure 1. Index map of the Norwegian-Greenland Sea, Arctic Ocean, North Atlantic Ocean, and adjacent areas. Vertical lines outline GSR; light line represents $1000-m$ depth contour; heavy lines - spreading ridges, dashed where extinct; light lines - transform faults; horizontal wavy lines - outcrops of basalt of the early Tertiary North Atlantic igneous province; $x$ 's on Ellesmere Island - location of Eocene vertebrate fossils; dots with numbers - selected DSDP sites; arrows bottom flow of Norwegian-Greenland Sea overflow water.
- Denmark Strait, a narrow passageway as deep as $600 \mathrm{~m}$ between Iceland and Greenland, through which cold water from the Norwegian-Greenland Sea flows southward into the western North Atlantic;

- Iceland Plateau, consisting of Iceland and the shelf and marginal slopes contiguous to it, a broad intraoceanic volcanic plateau characterized by active rifting, tholeiitic and alkalic basalts, a crust much thicker than normal oceanic crust, several NW-trending transform faults, and subaerially outcropping rocks as old as $16 \mathrm{Ma}$;

- Iceland-Faeroe Ridge, a broad, flat-topped, NW-trending ridge about $400 \mathrm{~m}$ deep, bordered by two shallow SWtrending troughs on its NW and SE margins. The Ridge is thought to be underlain by volcanic rocks similar to but older than those of Iceland (tholeiitic basalts recovered from DSDP Site 336 on the nor th flank of the Ridge, about $900 \mathrm{~m}$ below the ridge crest, have $\mathrm{K} / \mathrm{Ar}$ ages of 37-47 Ma).

- Faeroe Islands block, a triangular-shaped platform flanked on all sides by escarpments that slope away from the block, and capped by subaerial exposures of Lower Tertiary tholeiitic basalts in the Faeroe Islands;

the relatively narrow marine channel that flanks the Faeroe Islands block to the SE (Faeroe-Shetland Channel) and SW (Faeroe Bank Channel), which is locally as deep as $1200 \mathrm{~m}$ and is filled at least in part by a thick sequence of Cretaceous and Paleogene sediments that are being explored for hydrocarbons; and

- a series of submarine banks and ridges of varying shape and size, all located along the west margin of Scotland SW of the Faeroe Bank Channel, including the Bill Bailey and Lousy Banks, both generally thought to be similar to the Faeroe Islands block, and the west-trending WyvilleThomsen and Ymir Ridges; of which the latter have substantial cover of sediment drift on basalts that can be traced in seismic reflection profiles under the FaeroeShetland Channel from the Faeroe Islands block.

The GSR thus consists of (a) two major volcanic plateaus that are thought to have been constructed on oceanic crust concomitant with sea-floor spreading (Iceland Plateau and Iceland-Faeroe Ridge), (b) isolated blocks of continental crust overlain by Paleocene basalts (Faeroe Islands block and adjacent smaller blocks to the south), (c) a major curvilinear deep basin that separates these blocks from the continental margin of western Europe (Faeroe-Shetland and Faeroe Bank Channels), and (d) several narrow SW-trending troughs that, along with the Faeroe Bank and Faeroe-Shetland Channels, form pathways for the southward transport of water from the Norwegian-Greenland Sea to the Atlantic (the Denmark Strait and the troughs along the margins of the IcelandFaeroe Ridge). 
The history of the GSR is critical not only to an understanding of the tectonic development of that region, but also for solving many other problems of broader interest. On the basis of the remarkable similarities between their land vertebrates during part of the early Tertiary, the GSR in the 1800 s was thought to have been an early Tertiary land bridge (the Thulean) that connected North America and Western Europe. The recognition of lower Tertiary lateritic paleosols at DSDP Site 336 (Fig. 3) gave new support to this hypothesis.

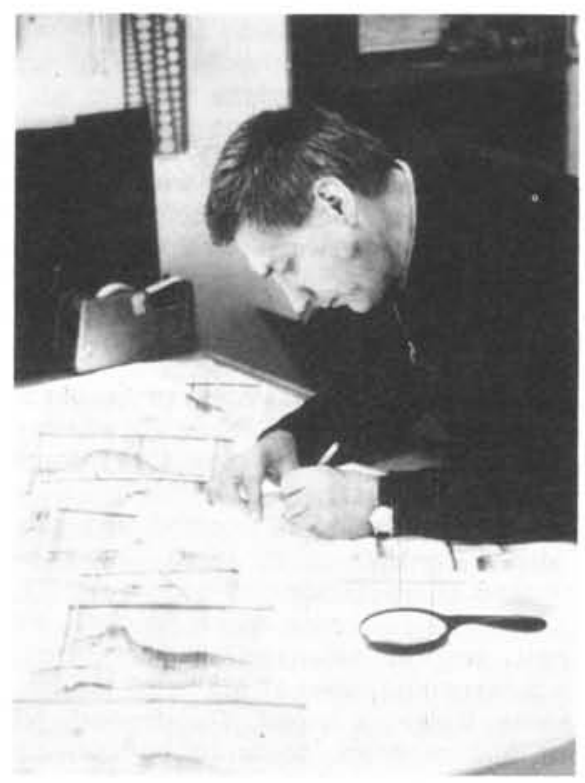

Dr. G. Udintsev (Moscow) studying seismic profiles on DSDP Leg 38, Norwegian-Greenland Sea.

A flow of marine waters across the ridge in the early Tertiary, however, is required to explain similarities in marine microfauna on opposite sides. Colder water flowing southward from the Norwegian-Greenland Sea and Arctic Ocean is thought to have been responsible for widespread submarine erosion in the North Atlantic near the base of the Oligocene, for the subsequent deposition of major sediment drifts or contourite ridges as far south as the Blake-Bahamas plateau region, and for the establishment of worldwide bottom water circulation patterns. The subsidence history of the ridge thus is of major concern to a number of subdisciplines.

On the basis of geophysical, geochemical, and geological criteria, Iceland is thought by many workers to be a major example of hot spot activity. However, the transition from Paleocene volcanism on the continental margins of Greenland, the Faeroe Islands and northern British Isles to later volcanism on the Iceland-Faeroe Ridge and on Iceland is not well understood. Other areas of proposed hot spot volcanism, such as the Yermak Plateau off northern Greenland, the Voring Plateau, Jan Mayen Island, and the Davis Strait area (Fig. 1) have not been clearly related to the history of the GSR.

The pattern of sea-floor spreading in the region, as recorded in magnetic anomalies, has also been complex, and the development of the GSR is clearly a key to understanding the spreading history of the areas adjacent to it. Pre-Tertiary openings along Rockall Trough and the Faeroe-Shetland Channel, and possibly in the Inner Voring Plateau basin, were succeeded by early Tertiary spreading and extensive volcanism involved in the development of the GSR. From the
GSR nor th to the Jan Mayen Fracture Zone (Fig. 2), there are at least two, and possibly three, spreading ridges that were active in the Tertiary and that have migrated or jumped westward through time.

By contrast, only one axis of spreading existed north of the Jan Mayen Fracture Zone and one south of the GSR, the Reykjanes Ridge. The Jan Mayen Ridge (Fig. 2) is generally thought to be a continental fragment that broke from East Greenland in the Oligocene or Miocene. Deciphering the history of the GSR is essential to defining the history of the transition from an early three-plate spreading geometry that included the movement of North America away from Greenland to the post-early Oligocene two-plate geometry in which Nor th America and Greenland moved as a single plate.

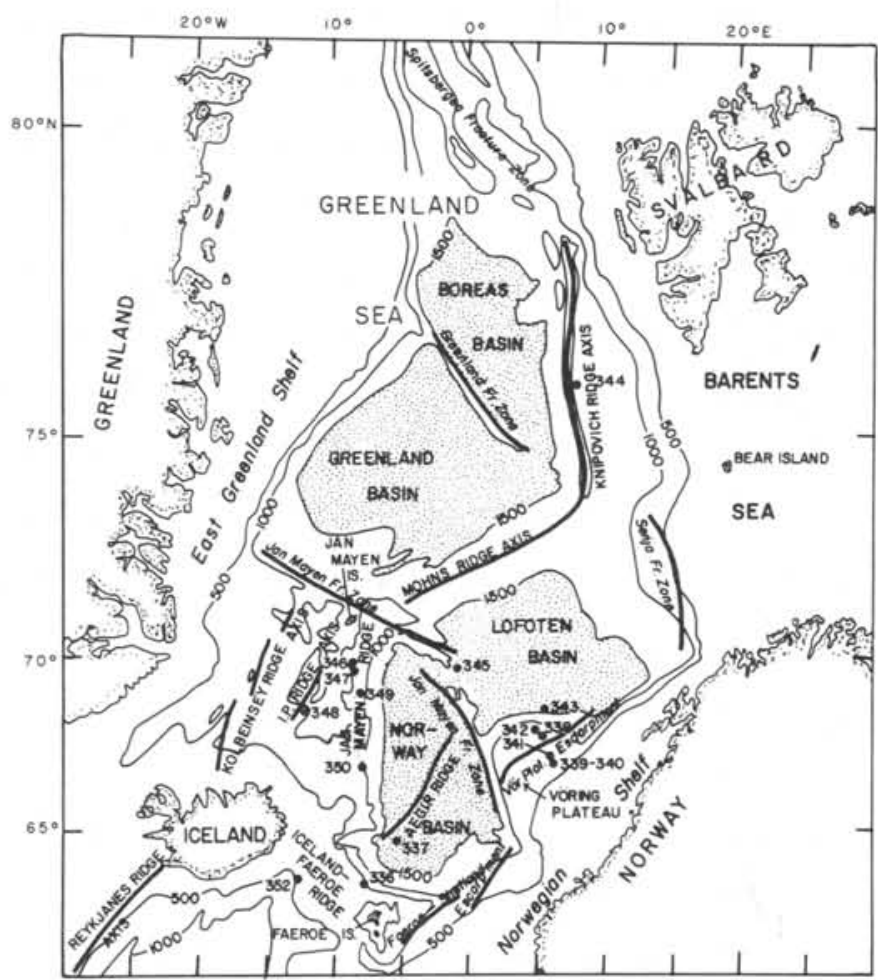

Figure 2. Index map of Norwegian-Greenland Sea showing main geographical features and locations of DSDP sites. Bottom contours in nominal fathoms (sound velocity 800 $\mathrm{fm} / \mathrm{s}$ ).

\section{Marine Techniques}

A number of new marine techniques have been used in or are applicable to the study of the GSR. For example, recent marine seismic reflection and refraction techniques that utilize multichannel systems and multiple ships, permit the accumulation of new types of useful data. Modern oceanbottom seismometers have the following advantages: low cost, ability to operate over long periods of time, fixed location, possible emplacement in drill holes, and the ability to record both natural earthquakes and artificial signals generated from ships. The resulting seismograms provide information on microearthquake activity, low-velocity zones associated with magma chambers along spreading ridges, and velocity profiles within the mantle, ocean crust, and sediment cover. Another new development is the MULTIGRAD system for heat-flow measurements. A towed probe constantly records sea temperatures, or can be placed in the 
bottom sediment fast enough to acquire direct heat-flow measurements. This instrument is particularly useful for detecting temperature anomalies such as those associated with the release of hot water and gas in the active rifts along spreading ridges. Of great value is a multi-beam echosounding "seabeam" system which rapidly generates accurate maps of sea-floor topography along a strip of sea floor as wide as three-fourths of the water depth. Nearly instantaneous map plots and contouring permit scientists to direct the ship to areas of interest as they appear on the maps. There is also GLORIA, a dual-scan sonar instrument that can be towed to map large ocean-floor features such as the GSR. Special techniques for the study of the bottom (benthonic) boundary layer of the ocean are also available. This layer differs from overlying water in salinity, temperature, flow velocity, content of radioactive elements, and content of suspended sediment.

Other improvements include:

- the hydraulic piston corer, which obtains undisturbed cores in the upper several hundred metres of each hole,

- deeper penetration because of re-entry ability and better designed drill bits,

- pressurized core barrel, which obtains undisturbed cores from sediments containing gas under pressure,

- oriented cores for magnetostratigraphic work,

- direct heat-flow measurements,

- drilling in deeper water by means of lighter aluminum drill strings,

- new well-logging techniques,

- drilling in hot rock,

- casing holes for later reoccupation,

- drilling directly into bedrock areas that do not have sediment cover,

- improved seismic profiling techniques, and

- development of downhole instruments such as heat-flow probes and seismometers.

\section{General Structure and Geophysical Properties}

Recent work has led to the conclusion that the GSR has grown concomitantly with active sea-floor spreading to the south; active shifting of spreading axes was confined to the area north of the ridge. Studies of the crustal structure of Iceland show that it basically consists of overthickened oceanic crust on an upper mantle that is characterized by atypically low mantle seismic velocities. The entire Icelandic block may thicken through time by a process of underplating that possibly involves the broad zone of partially melted material beneath Iceland.

The Davis Strait region to the west, (Fig. 1) a topographically high part of the rift between Greenland and Canada that is now an area of active petroleum exploration, is considered to be a high-standing area of sea floor produced during two separate phases of spreading, the second characterized by hot spot activity. The East Greenland continental margin also exhibits a complex spreading pattern, in addition to abundant early Tertiary plutons and plateau basalts, rift basins, and an offshore prograding wedge of marine sediments that has almost closed off the Denmark Strait.

The Iceland-Faeroe Ridge consists of overthickened oceanic crust that is more than $30 \mathrm{~km}$ thick and was probably constructed of numerous volcanoes and flood basalts. To date, it has not been possible to trace over the ridge or through it the magnetic anomalies characteristic of sea-floor spreading processes to the south and north. Data from the crust beneath the Faeroe Islands show that the $5-6 \mathrm{~km}$ thick, little-deformed Paleocene basalts that form the only outcrops on these islands are probably underlain by continental crust. Initial strontium isotope ratios of 1.0711 also indicate a continental foundation. A future $2-\mathrm{km}$-deep drillhole may yield conclusive evidence. A qualitative explanation is that the regional topographic, geochemical, magnetic, and gravity

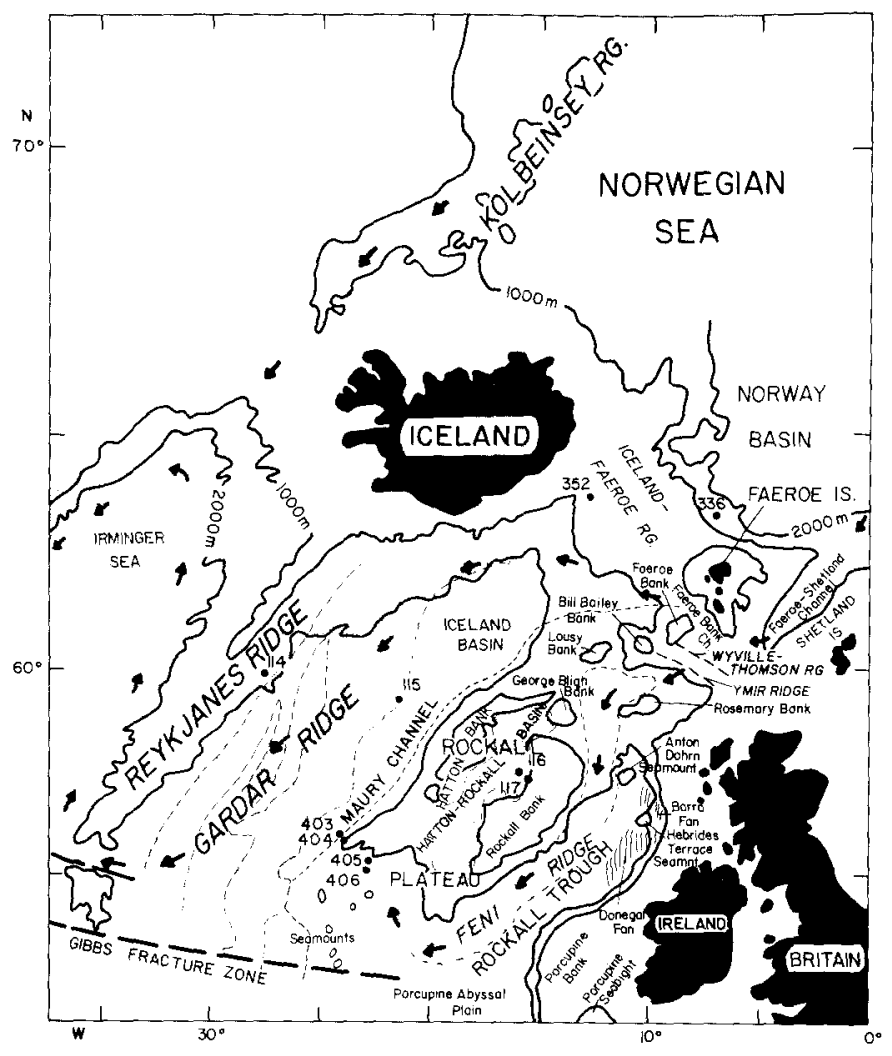

Figure 3. Index map of the NE Atlantic Ocean and adjacent areas, showing the main geographical features and location of DSDP sites. Small arrows indicate flow direction of Norwegian Sea bottom water. Stippled areas are regions of sediment drift or contourite ridges. Bottom contours in meters.

anomalies indicate that the basalts of the Faeroe Islands, East Greenland, Iceland-Faeroe Ridge, and Iceland represent progressively younger outpourings of volcanic material from the same hot spot.

\section{The Faeroe Island Block and Adjacent Areas}

The geology of the Faeroe-Shetland Channel has received considerable attention because of the extensive petroleum exploration taking place there. The Channel is underlain by an axial zone of volcanic rocks, with at least one plutonic complex of Campanian to Danian age. Deep to shallowmarine Campanian to Oligocene strata that prograded northwesterly across the Channel from source areas to the SE filled in part of the structure. Reconstructions of the movement of water masses between the Norwegian-Greenland Sea and the North Atlantic must consider the early development of the Channel. South of the Faeroes is the Wyville-Thomsen Ridge, a ridge which trends northwesterly between the Rockall Trough and Faeroe Channel, over which Norwegian-Greenland Sea water flows into Rockall Trough. Recent work indicates that the Ridge was underlain by early Tertiary basaltic lava and that throughout the Tertiary it had been a topographic high adjacent to the flanking FaeroeShetland and Faeroe Bank Channels to the north.

There is some dispute about the location of the continentocean boundary along the Faeroe-Shetland escarpment. One view is that the escarpment marks the continent-ocean boundary and that the area represents uplifted ocean floor adjacent to the continental margin. An opposing view, based on detailed multichannel seismic profiling and oil-well data 
indicates that the continent-ocean boundary lies to the seaward. According to this interpretation a gravity high in the area of the escarpment represents a sediment-covered seamount, and the area of controversy is pre-Tertiary sea floor overlapped by pre-Tertiary sediments and lower Tertiary basalts. Geological studies based on DSDP drilling on the Iceland-Faeroe Ridge demonstrate that redbeds of Eocene age above basalt on the north side of the ridge represent a lateritic paleosol. The paleosol indicates that the top of the Iceland-Faeroe Ridge did not subside below sea level until the Miocene, when its subsidence caused major changes in the circulation patterns between the Norwegian-Greenland Sea and the Atlantic.

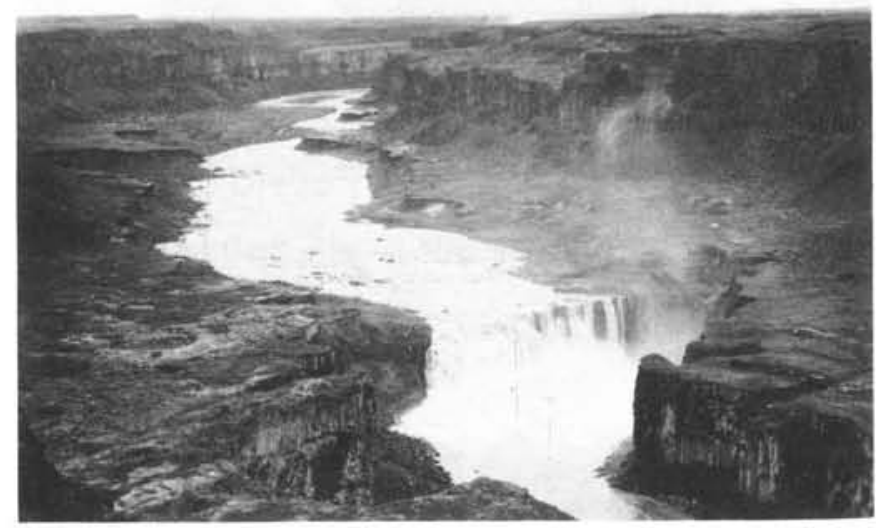

Neogene Plateau Basalts in NE Iceland.

\section{Other Geological Considerations}

The Mohns and Knipovich Ridges (Fig. 2) have volcanic rocks typical of mid-ocean ridges, but the geochemistry of lavas from Jan Mayen suggests a mantle-plume origin, perhaps distinct from that of Iceland. The rare-earth geochemistry of basalts from Iceland supports a mantle-plume origin in which the plume is in a declining phase of activity, because the youngest basalts are more like the mid-ocean ridge basalts. Basalts from the volcanically active Jan Mayen Ridge and Voring Plateau (Fig. 2) also geochemically resemble mantle plume-derived basalts, thus supporting the view that a second hot spot is present north of Iceland.

Remapping of the volcanics of East Greenland, which include gabbroic intrusives such as Skaergaard, a dike swarm trending parallel to the coast, and small post-extrusive syenite plutons, suggests a crustal thickness of about $5-6 \mathrm{~km}$. The presence of numerous faults in East Greenland suggests doming similar to that seen in the coeval basalts of the Faeroe Islands. - The rate of Tertiary basalt extrusion in East Greenland was similar to that in Iceland. Although the Greenland basalts were extruded through continental crust, they are tholeiites similar to those of Iceland.

Marine microfaunal correlations and paleoenvironmental interpretations in the Norwegian-Greenland Sea and North Atlantic strongly indicate that a connection between the two basins must have started by the early Eocene, just postdating the onset of spreading. The opening was probably through the Faeroe-Shetland Channel, and northward movement of Atlantic water resulted in warm climates as far north as Ellesmere Island. Studies of early Tertiary land vertebrates and other terrestrial fauna in North America and Western Europe suggest that a land bridge across the GSR must have connected these two areas at a time near the PaleoceneEocene boundary. This bridge need not have persisted more than a few million years and it must have been broken by the early Eocene, when the faunas began to be dissimilar.

A widespread unconformity in the North Atlantic at the Eocene-Oligocene boundary corresponds to the initiation of southward overflow of Norwegian-Greenland Sea water, probably chiefly through the Faeroe-Shetland Channel. This coincided with the suggestion that the Eocene-Oligocene boundary was a time of worldwide changes in circulation, global cooling, and in marine microfauna. These phenomena may have been caused by southward movement of colder bottom water. A number of paleooceanographic and paleobathymetric maps showing the evolution of the North Atlantic and Norwegian-Greenland Sea areas through the Cenozoic emphasize the importance of sea-level changes in all reconstructions, because many of the channels for transporting overflow waters are very shallow. An obvious conclusion is that the Iceland-Faeroe Ridge controlled climatic changes and the location of the North Atlantic ice cover during the Pliocene and Pleistocene.

Analyses of 35 pollen species from interbasaltic coals on the Faeroe Islands indicate a late Paleocene age for the coals. A controversial conclusion was that an exchange of water masses between the North Atlantic and the NorwegianGreenland Sea existed during the Pleistocene. This view was based on analyses of sediment cores that indicated that the Norwegian-Greenland Sea was not ice-covered during the last ice age.

Clay-mineral analyses and coccolith counts indicate that two distinct mineral provinces are recognizable in sediments from the Iceland-Faeroe Ridge areas; these provinces reflect movement of the main water masses. The first province, on the ridge itself, is basaltic in origin; the second, along the Scotland-Shetland shelf, is felsic in origin. Studies of the modern current regime over the GSR indicate that during the past 15 years, overflow of colder northern waters into the Iceland basin and Irminger Sea has been constant, with some inflow of Atlantic water into the Faeroe Bank Channel. Future work will consider seasonal changes in flow patterns, especially regarding the relations between the overflows and the formation of intermediate and deep waters in the Norwegian and Greenland Seas.

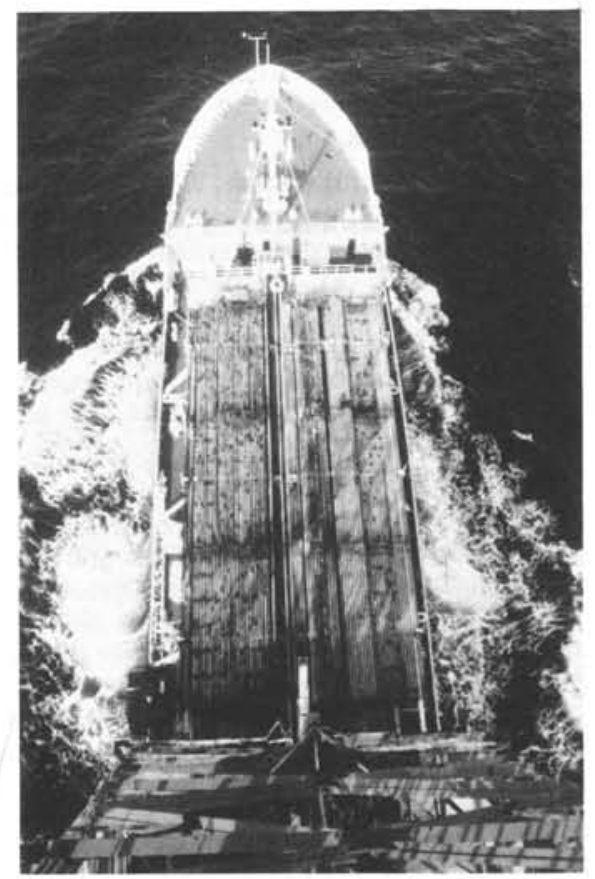

Bow of Glomar Challenger from derrick. 


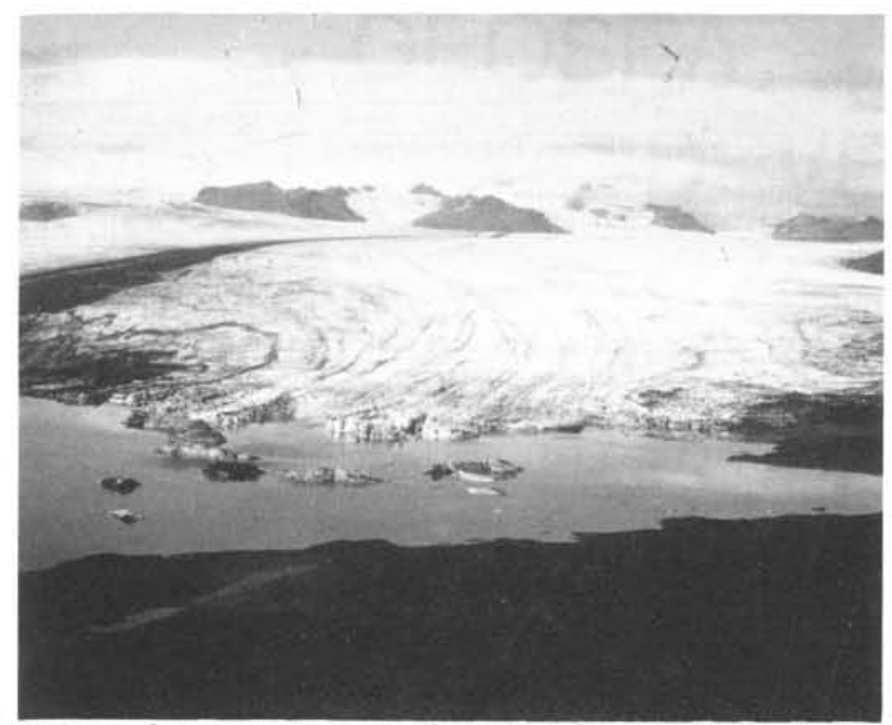

Icebergs forming, SE coast of Iceland, from Vatnajökull near Hestgerdi.

\section{Recommendations For Future Work}

Scientists working on the GSR agree that directions for future work include the following:

- Using seismic profiling and drilling, determine the age, character, and thickness of sediments deposited in the Denmark Strait, the Faeroe-Shetland Channel and the Faeroe Bank Channel, on the top and flanks of the IcelandFaeroe Ridge, and on the Wyville-Thomson and Ymir Ridges,

- Study the biostratigraphy, faunal provinces, paleobathymetry, and geohistory of these channels, plateaus, and ridges;

- Determine more precisely the age and character of the ocean floor around the margins of the GSR;

- Define the structure of the GSR, and particularly of the Iceland-Faeroe Ridge, using deeper penetration of the basaltic basement by drilling;

- Ascertain the subsidence history of the GSR preferably by drilling in the Faeroe-Shetland and Faeroe Bank channels;

- Examine and improve models for regional paleocirculation and paleogeography;

- Define the history of and reasons for the possible migration of hot spot activity and their relation to shifting of seafloor spreading ridges;

- Define thoroughly the timing, expression, and reason for the westward jump in spreading from Aegir Ridge to the Icelandic Plateau Ridge axis and Kolbeinsey Ridge, as well as the crustal structure and possible rifting of the Jan Mayen Ridge from Greenland;

- Define and estimate the amount of hot spot or plume hot spot volcanism by determining excess volumes of discharged basalt. The area or volume of crust per interval of time that is characterized by enrichment in radiogenic isotopes or light rare-earth elements can be used to make the estimates;

- Clarify the relation of the proposed Voring Plateau-Jan Mayen Island hot spot to the Icelandic and proposed Yermak Plateau hot spots needs. More heat-flow studies should be made along the GSR and adjacent areas;

- Determine the age of the oldest volcanic rocks on the Icelandic Plateau, probably by deep drilling, to permit a better understanding of the history of the plateau and its relation to sea-floor spreading;

- Determine the age of the youngest volcanic rocks on the Iceland-Faeroe Ridge, as well as the ages of volcanic rocks older than those recovered from DSDP Site 336;
- Use an integrated geochemical and petrologic analysis of early Tertiary basalts from the Davis Strait, East Greenland, the North Atlantic, the Norwegian Sea, the IcelandFaeroe Ridge, the Faeroe Islands, the Rockall Plateau, northern Britain, Northern Ireland, and the Voring Plateau to determine the nature of volcanic and magmatic processes and regional variations in the processes;

- Test the failed-arm or aulocogen hypothesis for the northern British Isles volcanic province;

- Analyze quantitatively regional and worldwide climatic changes based on movement of water masses over the GSR;

- Examine in a more quantitative manner and rigorously test the models proposed for the origin of sediment drifts and Eocene to Oligocene unconformities;

- Undertake long-term studies of suspended sediments in various water masses and channels to permit better understanding of sediment transport in the region;

- Study in an integrated manner early Tertiary laterites in the North Atlantic-Arctic region to provide more control on their possible climatic significance;

- Locate more fossil localities, particularly of early Tertiary terrestial vertebrates, in the North Atlantic-Arctic region to test the analyses of migration patterns;

- Perform multiple-ship seismic experiments along the GSR to better understand the structure of the ridge and of the continent-ocean boundaries.

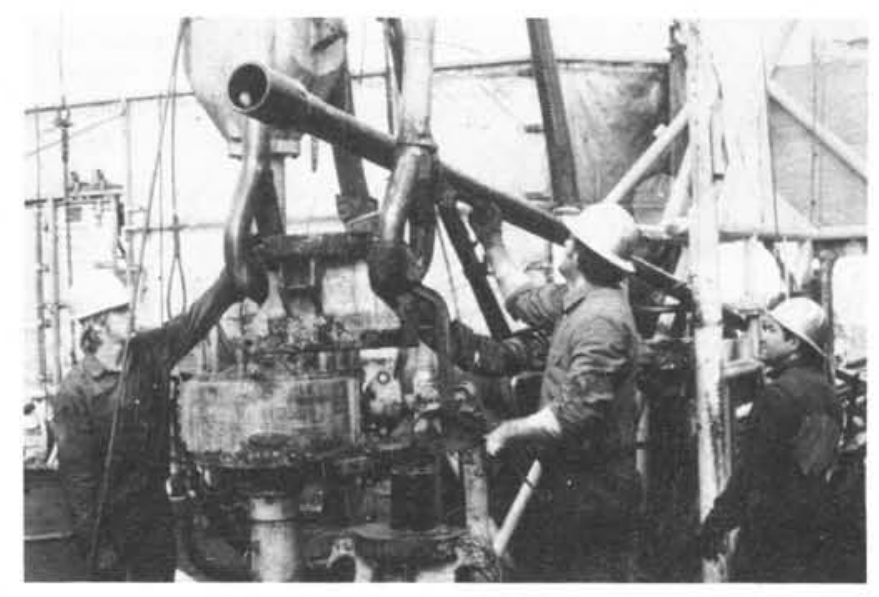

Roughnecks on drilling platform.

\section{Acknowledgements}

This paper is a summary of many contributions made at a NATO Advanced Study Institute entitled "The Structure and Development of the Greenland-Scotland Ridge: Methods and Concepts" held at the University of Padua Extension Center in Bressanone, northern Italy, on May 11-15, 1981. Because there were so many contributors at the conference, they are not identified individually in the text but listed as follows:

W.A. Berggren (U.S.A.); S. Bjornsson (Iceland); M.H.P. Bott (U.K.); K.L. Crane (U.S.A.); D. Eisma (Netherlands); O. Edholm (Norway); E.A. Hailwood (U.K.); E. Hock (Denmark); G. Kullenberg (Denmark); Y. Lancelot (U.S.A.); B. Larsen (Denmark); H.C. Larsen (Denmark); J. Lund (F.R.G.); J. Meincke (F.R.G.); K.G. Miller (U.S.A.); C. Morelli (Italy); E.R. Neuman (Norway); P.H. Nielsen (Denmark); A.G. Nunns (U.S.A.); E. Olaussen (Sweden); V. Renard (France); M.F. Ridd (U.K.); D.G. Roberts (U.K.); R. Rudloff (F.R.G.); J.-G. Schilling (U.S.A.); A.M. Spencer (Norway); D. Schnitker (U.S.A.); D.K. Smythe (U.K.); S.V. Srivastava (Canada); P.L. Stoffa (U.S.A.); F. Strauch (F.R.G.); M. Talwani (U.S.A.); J. Theide (Norway); B.E. Tucholke (U.S.A.); P.R. Vogt (U.S.A.); D. Voppel (F.R.G.); and R. Waagstein (Denmark). 
Bowes, D.R. and Leake, B.E. (eds.), 1978, Coastal evolution in northwestern Britain and adjacent regions: Geol. Journ. Spec. Issue No. 10, 492p.

Eldholm, O. and Thiede, J. 1980, Cenozoic continental separation between Europe and Greenland: Palaeogeography, Palaeoclimatology, Palaeoecology, v. 30, p.243-259.

Kristjansson, L. (ed.), 1974, Geodynamics of Iceland and the North Atlantic area: Dordrecht, O. Reidel Pub. Co., 323p.

Nilsen, T.H. and Kerr, D.R., 1978, Paleoclimatic and paleogeographic implications of a lower Tertiary laterite (latosol) on the Iceland-Faeroe Ridge, North Atlantic region: Geol. Mag. v.115, p.153-182.

Rasmussen, J. and Noe-Nygaard, A., 1970, Geology of the Faeroe Islands: Denmarks Geologiske Undersogelse, Raekke Nr. 25, 142 p.

\section{ABOUT THE AUTHORS:}

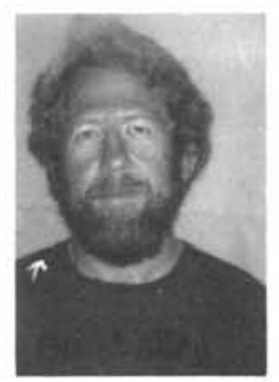

Tor H. Nilsen is a geologist in the Western Regional Geology Branch, U.S. Geological Survey, Menlo Park, California. His Ph.D. thesis at the University of Wisconsin was a sedimentological study of alluvial fan deposits of the Old Red Sandstone (Devonian) in western Norway. He has worked on slope stability hazards in the San Francisco Bay region, turbidite sequences in the western United States and Italy, and was a participant on DSDP Leg 38 to the NorwegianGreenland Sea.

\section{EPISODES}

Geological Newsmagazine of the IUGS

I am interested in subscribing to EPISODES (\$15 U.S. a year)

Name:

Address:

City: Province/State

Country: Postal Code:

Send to: Editor, EPISODES

Room 177, 601 Booth Street,

Ottawa, Ontario, Canada

KIA OE \&

Telephone: (613) 995-4927
Saxov, S. (ed.), 1982, Structure and development of the Greenland-Scotland Ridge: New concepts and methods: New York, Plenum Press, in press.

Talwani, M. and Eldholm, O., 1977, Evolution of the Norwegian-Greenland Sea: Geol. Soc. of Am. Bull., v.88, p.969-999.

Talwani, M., Udintsev, G. et al., 1976, Initial Reports of the Deep Sea Drilling Project, v.38, Washington, D.C. (U.S. Government Printing Office), 1256p.

Vogt, P.R., Perry, R.K., Feden, R.H., Fleming, H.S., and Cherkis, N.Z., 1981, The Greenland-Norwegian Sea and Iceland environment: Geology and Geophysics, in Nairn, A.E.M., Churkin, M. Jr., and Stehli, F.G., (eds.), The Ocean Basins and Margins, v.5, The Arctic Ocean: New York, Plenum Press, p.493-598.

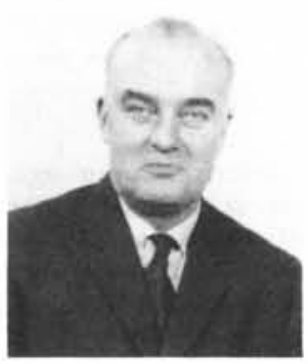

Svend Saxov is Professor of Applied Geophysics at Aarhus University, Denmark. His research activities centre on gravimetry in Scandinavia, the Faeroes, Iceland and Greenland and, more recently, on geothermics. He is a member of the NATO Advisory Panel on Marine Sciences and has served as a consultant on prospecting for hydrocarbons, minerals and groundwater. He is also editor of Geoexploration Monographs and President of Editerra.

\section{NEW IUGS DIRECTORY NOW AVAILABLE}

The second edition (1981) of the IUGS Directory was recently released by Dr. C.C. Weber, the Union's Secretary-General. It lists the 91 National Adhering Bodies, and addresses of some 1500 people who are officers or members of IUGS Committees, Commissions, Joint Programs or Affiliated Associations.

Copies may be obtained for $\$ 6.00$ (U.S.) from:

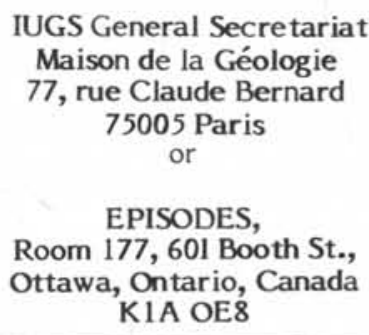

